\title{
Profil Self Regulation Mahasiswa Pendidikan Matematika FKIP Universitas Riau di Masa Pandemi Covid-19
}

\author{
Hesty Marwani Siregar ${ }^{1 \bowtie}$ dan Syarifah Nur Siregar ${ }^{2}$ \\ ${ }^{1,2}$ Prodi Pendidikan Matematika, Universitas Riau
}

\begin{abstract}
Info Artikel Abstract
Sejarah Artikel:

Diterima 23 Nov 2020

Direvisi 4 Apr 2021

Disetujui 17 Apr 2021

Keywords: Self

Regulation, Pendidikan

Matematika, Covid-19

\section{Paper type:}

Research paper

This research aims to determine the description of students' self-regulation of Mathematics Education FKIP at the Universitas Riau during the Covid-19 pandemic. The subjects in this study were 121 students of Mathematics Education, FKIP, Universitas Riau. This research uses a descriptive quantitative approach. The data obtained from students was the score of self-regulation of Mathematics Education students, FKIP, Universitas Riau during the Covid-19 pandemic. The research that was conducted showed that the students' self-regulation were at a moderate level as many as 21 people (17.36\%), at a high level as many as 80 people (66.12\%), and at a very high level as many as 20 people (16.53\%). Meanwhile, the achievement of students' self-regulation for each indicator consisted of a goal-setting indicator of $85.74 \%$ with a good category, an indicator of environment structuring of $80.48 \%$ in a good category, an indicator of task strategies of $73.17 \%$ in a fair category, an indicator of time management is $63.22 \% \%$ in a fair category, an indicator of seeking help is $73.76 \%$ in a fair category, and self-evaluation indicator is $87.6 \%$ in a very good category. Based on the self-regulation category of each student and the percentage of selfregulation achievement for each indicator, it can be said that the students of Mathematics Education FKIP Universitas Riau were able to adapt while taking online classes during the Covid19 pandemic by having good self-regulation.
\end{abstract}

\begin{abstract}
Abstrak
Penelitian ini bertujuan untuk mengetahui gambaran self regulation mahasiswa Pendidikan Matematika FKIP Universitas Riau di masa pandemi Covid-19. Subjek pada penelitian ini yaitu 121 mahasiswa Pendidikan Matematika, FKIP, Universitas Riau. Penelitian ini menggunakan pendekatan kuantitatif deskriptif. Data yang diperoleh dari mahasiswa adalah skor self regulation mahasiswa Pendidikan Matematika FKIP Universitas Riau di masa pandemi Covid-19. Penelitian yang dilakukan memperoleh hasil bahwa self regulation mahasiswa berada pada kategori sedang sebanyak 21 orang $(17,36 \%)$, kategori tinggi sebanyak 80 orang $(66,12 \%)$, dan kategori sangat tinggi sebanyak 20 orang $(16,53 \%)$. Sementara, pencapaian self regulation mahasiswa untuk masing-masing indikator terdiri dari indikator penetapan tujuan sebesar $85,74 \%$ dengan kategori baik, indikator penataan lingkungan sebesar $80,48 \%$ dengan kategori baik, indikator strategi tugas sebesar $73,17 \%$ dengan kategori cukup, indikator manajemen waktu sebesar $63,22 \% \%$ dengan kategori cukup, indikator pencarian bantuan sebesar 73,76\% dengan kategori cukup, dan indikator evaluasi diri sebesar 87,6\% dengan kategori sangat baik. Berdasarkan kategori self regulation masing-masing mahasiswa dan persentase pencapaian self regulation untuk tiap indikator, dapat dikatakan bahwa mahasiswa Pendidikan Matematika FKIP Universitas Riau sudah mampu beradaptasi selama mengikuti perkuliahan daring di masa pandemi Covid-19 dengan memiliki self regulation yang baik.
\end{abstract}

(C) 2021 Universitas Muria Kudus

Alamat korespondensi: p-ISSN 2615-4196

Program Studi Pendidikan Matematika

e-ISSN 2615-4072

Fakultas Keguruan dan Ilmu Pendidikan Universitas Muria Kudus

Kampus UMK Gondangmanis, Bae Kudus Gd. L. 1t I PO. BOX 53 Kudus

Tlp (0291) 438229 ex.147 Fax. (0291) 437198

E-mail: hesty.marwani@lecturer.unri.ac.id 
Hesty Marwani Siregar dan Syarifah Nur Siregar

Anargya: Jurnal Pendidikan Matematika, Vol. 4 No.1, April 2021

https://dx.doi.org/10.24176/anargya.v4i1.5601

\section{PENDAHULUAN}

Penyakit coronavirus 19 (COVID-19) adalah infeksi virus yang sangat mudah menular dan patogen yang disebabkan oleh Coronavirus 2 (SARS-CoV-2), sindrom pernapasan akut parah, yang muncul di Wuhan Cina dan menyebar ke seluruh dunia (Shereen, Khan, Kazmi, Bashir, \& Siddique, 2020). Sebagian besar orang yang terinfeksi virus COVID-19 akan mengalami penyakit pernapasan level ringan hingga sedang, dan sembuh tanpa memerlukan perawatan khusus. Orang lanjut usia dan orang yang memiliki riwayat penyakit jantung, diabetes, pernapasan kronis, dan kanker dapat mencapai level berat jika terinfeksi virus COVID-19 ini.

Dampak wabah virus corona dirasakan di berbagai sektor kehidupan termasuk di sektor pendidikan. Di Indonesia, Pemerintah Pusat hingga Pemerintah Daerah, sepakat untuk mengeluarkan kebijakan pembatasan hingga menghentikan aktivitas di lingkungan lembaga pendidikan. Hal ini dilakukan sebagai upaya untuk mencegah meluasnya penularan virus corona. Namun, pentingnya pendidikan bagi seluruh umat manusia menyebabkan aktivitas pendidikan harus tetap dapat dilakukan di luar lingkungan sekolah. Solusi yang ditawarkan pemerintah adalah mengganti pembelajaran tatap muka dengan melakukan kegiatan pembelajaran di rumah melalui sistem pembelajaran jarak jauh dan daring. Solusi ini merujuk pada Surat Edaran Mendikbud Nomor 3 Tahun 2020 tentang Pencegahan Covid19 pada Satuan Pendidikan, dan Nomor 36962/MPK.A/HK/2020.

Proses perkuliahan di masa pandemi covid19 yang menggunakan akses internet, menuntut mahasiswa untuk bisa belajar secara mandiri. Mahasiswa harus aktif berpartisipasi dalam proses perkuliahan dan aktif menggali informasi terkait materi kuliah yang dipelajari. Mahasiswa juga harus dapat mengatur waktu untuk mengikuti perkuliahan dan untuk mengerjakan tugas yang diberikan. Hal ini tentu berbeda dengan paradigma pembelajaran lama yaitu guru memberikan pengetahuan kepada siswa secara pasif tanpa memberikan kesan pada memori siswa (Kusuma \& Hamidah, 2019).

Optimalnya kemandirian belajar mahasiswa akan mempengaruhi kemampuan pemecahan masalah matematik (Meisura, Risnawati, \& Amir MZ, 2019). Kemampuan pemecahan masalah ini akan berguna dalam penyelesaian tugas-tugas mahasiswa. Schunk \& Zimmerman (Alfiana, 2013) menyatakan bahwa belajar mandiri atau yang disebut juga self regulation, merupakan suatu proses belajar yang dipengaruhi oleh kemampuan untuk meregulasi diri secara mandiri dalam melakukan kegiatan belajar.

Dengan self regulation, mahasiswa dapat memantau berhasil tidaknya selama proses pembelajaran, yang mengakibatkan motivasi belajar juga akan meningkat ketika dirasa metode pembelajaran yang diterapkan berhasil (Fung, Yuen, \& Yuen, 2014). Pernyataan ini sesuai dengan penelitian yang dilakukan oleh Velayutham, Aldridge, \& Fraser (2012) yang menyelidiki pengaruh keyakinan motivasi siswa dalam pembelajaran sains terhadap regulasi diri di kelas sains. Hasil dari analisis menunjukkan bahwa motivasi merupakan prediktor kuat dari self regulation siswa dalam pembelajaran sains.

Agar dapat mengikuti kegiatan pembelajaran dengan baik di masa pandemi Covid-19, mahasiswa harus memiliki self regulation yang baik di setiap matakuliah. Salah satunya dengan mengenali dan menetapkan cara belajar mereka masing-masing. Sesuai dengan yang dikatakan oleh bahwa setiap manusia memiliki gaya belajar yang unik (Fathani, 2019).

Bandura menyatakan bahwa self regulation adalah kemampuan untuk memanajemen dan melakukan suatu tingkah laku yang dilakukan dalam upaya meningkatkan performa dirinya sehingga dapat mencapai tujuan yang diinginkan (Chairani \& Subandi, 2010). Self regulation mengacu pada pembelajaran yang dihasilkan dari pemikiran dan perilaku yang dihasilkan sendiri oleh mahasiswa yang berorientasi secara sistematis untuk mencapai tujuan pembelajaran mereka (Mutawah, Thomas, \& Khine, 2017). Self regulation merupakan tindakan yang dilakukan seseorang untuk mengontrol tidak hanya tingkah laku tetapi juga pemikiran dan perasaannya, kemudian mengevaluasi tindakan tersebut agar hasil yang diharapkan dapat tercapai.

Self regulation memerlukan pengaturan emosi, pikiran, dan perilaku dalam mencapai tujuan (Altun \& Erden, 2013). Self regulation terdiri dari 3 komponen, yaitu komponen kognitif, komponen motivasi, dan komponen metakognisi (Ramdass \& Zimmerman, 2011). Komponen kognitif dari self regulation merupakan komponen yang berkaitan dengan cara mahasiswa untuk mengolah informasi dan mempergunakannya untuk menyelesaikan tugas yang diberikan secara efektif dan efisien.

Komponen self regulation selanjutnya yaitu motivasi. Bagian dari motivasi yang penting dapat berpengaruh terhadap self 
Hesty Marwani Siregar dan Syarifah Nur Siregar

Anargya: Jurnal Pendidikan Matematika, Vol. 4 No.1, April 2021

https://dx.doi.org/10.24176/anargya.v4i1.5601

regulation adalah merancang tujuan, self efficacy, dan keinginan untuk memperoleh hasil yang baik. Self efficacy berpengaruh terhadap jalannya tindakan, tujuan dan tantangan yang diambil seseorang sekaligus komitmen mereka terhadap hal itu serta bagaimana seserang mengatasi hambatan dan tekanan dalam hidup (Ahyani, 2019).

Bagian dari motivasi yang juga termasuk self regulation diantaranya adalah mengetahui tujuan, rancangan diri, nilai, dan bagaimana mencari bantuan ketika mengalami kesulitan juga merupakan bagian. Semua bagian tersebut, secara bersama-sama berperan dalam menentukan tindakan yang dilakukan individu untuk mencapai tujuan. Keberhasilan mahasiswa dalam mengatur diri pada suatu kegiatan belajar akan meningkatkan motivasi mahasiswa untuk melanjutkan pembelajaran dan menentukan tujuan berikutnya.

Komponen ketiga dari self regulation yaitu metakognisi. Komponen metakognisi artinya mahasiswa menentukan tujuan kemudian mengevaluasi proses pencapaian tujuan tersebut untuk menunjang proses penyelesaian tugas. Mahasiswa dikatakan sudah melibatkan metakognisi dalam menyelesaikan tugas pada saat mahasiswa sudah mampu mencari akar permasalahan mengapa mereka tidak bisa memahami suatu materi dan mencari cara untuk mengatasi masalah tersebut.

Kemampuan self regulation yang dapat mengevaluasi diri sendiri berkaitan dengan seberapa banyak konsep yang mahasiswa pahami dari suatu materi dan cara untuk mengatasi hambatan yang dialami dalam belajar. Hal ini menjadikan self regulation sangat penting untuk dimiliki mahasiswa (Sari, 2014). Hal ini sejalan dengan pernyataan (Schunk, 2012) yaitu meningkatkan kinerja mahasiswa lebih efektif dilakukan dengan cara melatih self regulation daripada menggunakan pembelajaran regular. Penelitian yang dilakukan oleh Schunk \& Cox (Schunk, 2012) memperoleh hasil bahwa pada anak yang mengalami kesulitan belajar, ketika diberikan pelatihan self regulation, efikasi diri dan pencapaian belajarnya meningkat.

Mahasiswa yang memiliki self regulation yang baik akan memperoleh manfaat dalam pencapaian hasil belajarnya. Sebaliknya, mahasiswa yang self regulationnya belum optimal akan memperoleh dampak negatif. Maddux (Grahani \& Mardiyanti, 2019) menyatakan bahwa self regulation yang tidak berjalan sebagaimana mestinya akan mengakibatkan munculnya masalah psikologis yang serius, seperti depresi dan gangguan kecemasan. Karakteristik mahasiswa yang tidak dapat melakukan self regulation yaitu tidak mandiri, sulit beradaptasi, kemampuan bekerjasama kurang, kemampuan berpikir kritis kurang berkembang, tidak adanya motivasi, tidak percaya terhadap kemampuan diri sendiri, dan lain sebagainya (Manuella \& Mangunsong, 2017). Pada saat self regulation tidak optimal, mahasiswa akan sering menunda waktu penyelesaian tugas dan tidak serius dalam menyelesaikan tugas tersebut. Akibatnya, mahasiswa akan merasa frustasi terhadap tugas yang dibebankan dosen kepadanya (Alfiana, 2013).

Melihat pentingnya self regulation terhadap pencapaian tujuan seseorang, maka perlu rasanya untuk mengetahui gambaran self regulation mahasiswa agar diperoleh fakta tingkat self regulation yang dimiliki mahasiswa. Informasi tingkat self regulation ini selanjutnya dapat menjadi dasar bagi tindakan selanjutnya yang perlu dilakukan dosen agar mahasiswa memiliki self regulation yang optimal dan memperoleh hasil yang baik dalam belajar. Apalagi pada masa pandemi Covid-19 dimana perkuliahan dilaksanakan secara daring sepenuhnya, sehingga menuntut mahasiswa untuk lebih banyak belajar secara mandiri. Mahasiswa diharapkan dapat menyusun jadwal kegiatan belajar, memanajemen waktu belajar, disiplin dalam belajar, tmengerjakan tugas dengan baik dan mengumpulkannya tepat waktu, mampu menciptakan situasi dan kondisi yang nyaman untuk belajar, serta bisa menggunakan fasilitas yang tersedia dengan optimal.

Kondisi yang terjadi selama perkuliahan di masa pandemi Covid-19, masih ada mahasiswa yang tidak mengumpulkan tugas yang diberikan tepat waktu. Berdasarkan tanya jawab dengan beberapa mahasiswa, ada mahasiswa yang tidak memahami materi yang diajarkan dosen. Agar dapat menyelesaikan tugas, ada mahasiswa yang meminta bantuan temannya untuk mengajarkan materi yang tidak dipahami, namun ada pula yang hanya menyalin jawaban tugas temannya. Selanjutnya, pada perkuliahan di masa pandemi ini, juga terdapat mahasiswa yang kurang disiplin, baik dalam jam kehadiran perkuliahan virtual, maupun dalam masalah kehadiran.

Untuk mengoptimalkan pencapaian self regulation, dapat dilakukan dengan berbagai cara. Penggunaan berbagai model pembelajaran terbaru yang telah ramai digunakan oleh pendidik agar aktivitas dan hasil belajar mahasiswa meningkat, menjadi salah satu usaha untuk meningkatkan 
Hesty Marwani Siregar dan Syarifah Nur Siregar

Anargya: Jurnal Pendidikan Matematika, Vol. 4 No.1, April 2021

https://dx.doi.org/10.24176/anargya.v4i1.5601

mutu pendidikan (Suprihartini, 2019). Zamnah (2019) menyatakan bahwa melalui problemcentered learning dengan hands-on activity dalam pembelajaran, self regulated learning sebagian besar siswa yang menjadi objek penelitian berada pada kategori tinggi.

Berdasarkan manfaat pencapaian self regulation yang baik dalam diri seseorang, dan melihat kondisi yang dialami selama perkuliahan daring di masa pandemi Covid-19, oleh karena itu, penulis tertarik untuk menyelidiki gambaran self regulation mahasiswa Pendidikan Matematika FKIP Universitas Riau di masa pandemi Covid19. Tujuan dari penelitian ini untuk menjelaskan profil self regulation mahasiswa Pendidikan Matematika FKIP Universitas Riau di masa pandemi Covid-19. Dengan mengetahui gambaran self regulation tersebut, dosen dapat mempertimbangkan tindakan selanjutnya yang perlu dilakukan agar self regulation mahasiswa lebih optimal ketika perkuliahan sepenuhnya harus dilakukan secara daring.

\section{METODE PENELITIAN}

Penelitian ini berfokus untuk mengetahui gambaran self regulation mahasiswa Pendidikan Matematika FKIP Universitas Riau di masa pandemi Covid-19. Rancangan kegiatan dalam penelitian ini yaitu 1) menentukan masalah yang akan dibahas yaitu mengenai gambaran self regulation mahasiswa pendidikan matematika FKIP Universitas Riau di masa pandemi Covid19, 2) melakukan studi literatur terkait self regulation, 3) menetapkan lokasi penelitian yaitu di Program Studi Pendidikan Matematika FKIP Universitas Riau, 4) melakukan studi pendahuluan dengan melihat bagaimana kondisi mahasiswa selama mengikuti perkuliahan daring di masa pandemi Covid-19, 5) menyusun instrumen pengumpulan data yaitu self regulation, 6) melakukan validasi kepada dua orang ahli terkait angket self regulation, 7) memperbaiki angket self regulation sesuai komentar ahli, 8) melakukan uji validitas dan reliabilitas angket, 9) melakukan perbaikan angket self regulation berdasarkan hasil uji validitas dan reliabilitas, 10) menyebarkan angket self regulation kepada mahasiswa pendidikan matematika FKIP Universitas Riau, 11) menganalisis hasil respon angket self regulation, 12) membuat narasi terkait gambaran self regulation mahasiswa pendidikan matematika FKIP Universitas Riau di masa pandemi Covid-19.
Penelitian ini menggunakan pendekatan kuantitatif deskriptif. Adapun subjek penelitian ini adalah mahasiswa Pendidikan Matematika FKIP Universitas Riau angkatan 2017, 2018, dan 2019 sebanyak 121 mahasiswa. Data yang diperoleh dari mahasiswa adalah skor self regulation mahasiswa Pendidikan Matematika FKIP Universitas Riau di masa pandemi Covid19. Penelitian ini dilaksanakan di Program Studi Pendidikan Matematika FKIP Universitas Riau.

Untuk mengumpulkan data pada penelitian ini, penulis menggunakan angket self regulation. Bentuk pernyataan pada angket disajikan dalam bentuk jawaban skala yang terdiri dari sangat setuju, setuju, tidak setuju, dan sangat tidak setuju. Responden diminta untuk memilih jawaban tersebut sesuai pribadinya masing-masing. Angket self regulation yang digunakan berisi 15 butir pernyataan.

Variabel dalam penelitian ini adalah self regulation mahasiswa dalam belajar di masa pandemi Covid-19. Definisi operasional dari self regulation pada penelitian ini yaitu tindakan yang dilakukan seseorang untuk mengontrol tidak hanya tingkah laku tetapi juga pemikiran dan perasaannya, kemudian mengevaluasi tindakan tersebut agar hasil yang diharapkan dapat tercapai. Oleh karena itu, aspek self regulation yang digunakan dalam penelitian ini yaitu penetapan tujuan, penataan lingkungan, strategi tugas, manajemen waktu, pencarian bantuan, dan evaluasi diri (Barnard, Lan, To, Paton, \& Lai, 2009).

Sebelum angket self regulation diberikan kepada mahasiswa yang menjadi subjek penelitian, angket tersebut dinilai terlebih dahulu. Untuk menguji kevalidan angket, penulis meminta bantuan dua ahli sebagai validator. Hasil validasi oleh kedua validator dapat dilihat pada Tabel 1 berikut.

Tabel 1. Ringkasan validasi skala self regulation oleh 2 validator

\begin{tabular}{lllll}
\hline \multirow{2}{*}{ Butir } & \multicolumn{2}{c}{ Validator 1 } & \multicolumn{2}{c}{ Validator 2 } \\
\cline { 2 - 5 } & $\begin{array}{l}\text { Rata- } \\
\text { Rata } \\
\text { Skor }\end{array}$ & Keterangan & $\begin{array}{l}\text { Rata- } \\
\text { Rata } \\
\text { Skor }\end{array}$ & Keterangan \\
\hline 1 & 3,2 & $\begin{array}{l}\text { Valid (perlu } \\
\text { perbaikan) }\end{array}$ & 3,2 & $\begin{array}{l}\text { Valid (perlu } \\
\text { perbaikan) }\end{array}$ \\
\hline 2 & 3,2 & $\begin{array}{l}\text { Valid (perlu } \\
\text { perbaikan) }\end{array}$ & 3,2 & $\begin{array}{l}\text { Valid (perlu } \\
\text { perbaikan) }\end{array}$ \\
\hline 3 & 3,2 & $\begin{array}{l}\text { Valid (perlu } \\
\text { perbaikan) }\end{array}$ & 3,2 & $\begin{array}{l}\text { Valid (perlu } \\
\text { perbaikan) }\end{array}$ \\
\hline 4 & 3,2 & $\begin{array}{l}\text { Valid (perlu } \\
\text { perbaikan) }\end{array}$ & 3,3 & $\begin{array}{l}\text { Valid (perlu } \\
\text { perbaikan) }\end{array}$ \\
\hline 5 & 3,2 & Valid & 3,3 & Valid \\
\hline 6 & 3,2 & Valid & 3,3 & Valid \\
\hline
\end{tabular}


Hesty Marwani Siregar dan Syarifah Nur Siregar

Anargya: Jurnal Pendidikan Matematika, Vol. 4 No.1, April 2021

https://dx.doi.org/10.24176/anargya.v4i1.5601

\begin{tabular}{lllll}
\hline \multirow{2}{*}{ Butir } & \multicolumn{2}{c}{ Validator 1 } & \multicolumn{2}{c}{ Validator 2 } \\
\cline { 2 - 5 } & $\begin{array}{l}\text { Rata- } \\
\text { Rata } \\
\text { Skor }\end{array}$ & Keterangan & $\begin{array}{l}\text { Rata- } \\
\text { Rata } \\
\text { Skor }\end{array}$ & Keterangan \\
\hline 7 & 3,2 & Valid & 3,4 & Valid \\
\hline 8 & 3,2 & $\begin{array}{l}\text { Valid (perlu } \\
\text { perbaikan) }\end{array}$ & 3,4 & Valid \\
\hline 9 & 3,2 & $\begin{array}{l}\text { Valid (perlu } \\
\text { perbaikan) }\end{array}$ & 3,3 & $\begin{array}{l}\text { Valid (perlu } \\
\text { perbaikan) }\end{array}$ \\
\hline 10 & 3,2 & $\begin{array}{l}\text { Valid (perlu } \\
\text { perbaikan) }\end{array}$ & 3,3 & $\begin{array}{l}\text { Valid (perlu } \\
\text { perbaikan) }\end{array}$ \\
\hline 11 & 3,2 & $\begin{array}{l}\text { Valid (perlu } \\
\text { perbaikan) }\end{array}$ & 3,2 & $\begin{array}{l}\text { Valid (perlu } \\
\text { perbaikan) }\end{array}$ \\
\hline 12 & 3,2 & Valid & 3,4 & Valid \\
\hline 13 & 3,2 & $\begin{array}{l}\text { Valid (perlu } \\
\text { perbaikan) }\end{array}$ & 3,4 & $\begin{array}{l}\text { Valid (perlu } \\
\text { perbaikan) }\end{array}$ \\
\hline 14 & 3,2 & Valid & 3,4 & Valid \\
\hline 15 & 3,2 & $\begin{array}{l}\text { Valid (perlu } \\
\text { perbaikan) }\end{array}$ & 3,4 & $\begin{array}{l}\text { Valid (perlu } \\
\text { perbaikan) }\end{array}$ \\
\hline
\end{tabular}

Setelah angket diperbaiki sesuai saran kedua validator, angket tersebut kemudian diujikan kepada mahasiswa angkatan 2014, 2015, dan 2016. Untuk mengolah data validitas butir item pernyataan, terlebih dahulu penulis mengubah skor self regulation yang merupakan data ordinal ke interval dengan menggunakan metode MSI. Selanjutnya data tersebut diolah menggunakan korelasi Pearson Product Moment untuk menentukan validitasnya dan Cronbach's Alpha untuk menentukan reliabilitasnya. Hasil validitas dan reliabilitas skala self regulation dapat dilihat pada Tabel 2 berikut.

Tabel 2. Data hasil uji coba validitas skala self regulation

\begin{tabular}{cccccc}
\hline Butir & $r_{x y}$ & Kriteria & $\mathbf{t}_{\text {hitung }}$ & $\mathbf{t}_{\text {tabel }}$ & Interpretasi \\
\hline 1 & 0,51 & Sedang & 4,49 & 2 & Valid \\
\hline 2 & 0,72 & Tinggi & 7,73 & 2 & Valid \\
\hline 3 & 0,52 & Sedang & 4,65 & 2 & Valid \\
\hline 4 & 0,5 & Sedang & 4,38 & 2 & Valid \\
\hline 5 & 0,46 & Sedang & 3,93 & 2 & Valid \\
\hline 6 & 0,64 & Tinggi & 6,26 & 2 & Valid \\
\hline 7 & 0,54 & Sedang & 4,9 & 2 & Valid \\
\hline 8 & 0,7 & Tinggi & 7,37 & 2 & Valid \\
\hline 9 & 0,68 & Tinggi & 7,03 & 2 & Valid \\
\hline 10 & 0,58 & Sedang & 5,42 & 2 & Valid \\
\hline 11 & 0,67 & Tinggi & 6,88 & 2 & Valid \\
\hline 12 & 0,61 & Tinggi & 5,79 & 2 & Valid \\
\hline 13 & 0,56 & Sedang & 5,16 & 2 & Valid \\
\hline 14 & 0,48 & Sedang & 4,12 & 2 & Valid \\
\hline 15 & 0,48 & Sedang & 4,14 & 2 & Valid \\
\hline
\end{tabular}

Tabel 3. Data hasil uji coba reliabilitas skala self regulation

\begin{tabular}{ccccc}
$\mathbf{r}$ & Kriteria & $\mathbf{t}_{\text {hitung }}$ & $\mathbf{t}_{\text {tabel }}$ & Interpretasi \\
\hline 0,86 & Tinggi & 12,62 & 2 & Reliabel \\
\hline
\end{tabular}

Setelah angket self regulation valid dan reliabel, angket tersebut kemudian disebarkan kepada mahasiswa yang menjadi subjek penelitian. Data skor self regulation tersebut kemudian diolah menggunakan teknik statistik deskriptif. Teknik statistik deskriptif merupakan metode statistik yang digunakan untuk memperoleh informasi mengenai suatu data tanpa melalui prosedur pengujian hipotesis dan menggeneralisasikan hasil pengujian.

Data skor self regulation yang diperoleh kemudian dikategorikan dengan merujuk pada kategori yang disusun Azwar (2012) yang dapat dilihat pada Tabel 4 berikut.

Tabel 4. Kategori self regulation

\begin{tabular}{|c|c|}
\hline Rentang Skor & Kategori \\
\hline $\mathrm{x}<24$ & Sangat Rendah \\
\hline $24 \leq \mathrm{x}<33$ & Rendah \\
\hline $33 \leq \mathrm{x}<42$ & Sedang \\
\hline $42 \leq \mathrm{x}<51$ & Tinggi \\
\hline $\mathrm{x} \geq 51$ & Sangat Tinggi \\
\hline
\end{tabular}

Data skor mahasiswa yang diperoleh kemudian dikelompokkan berdasarkan kategori tersebut dan dihitung persentasenya untuk masing-masing kategori. Selanjutnya penulis juga menentukan persentase pencapaian masingmasing indikator self regulation yang digunakan dan persentase pencapaian self regulation secara keseluruan. Kategori persentase ketercapaian self regulation yang digunakan merujuk pada Purwanto (2012) seperti disajikan pada Tabel 5 di bawah ini.

Tabel 5. Kategori persentase pencapaian self regulation

\begin{tabular}{cc}
\hline Persentase & Kategori \\
\hline $86 \leq \mathrm{p} \leq 100$ & Sangat baik \\
\hline $76 \leq \mathrm{p}<86$ & Baik \\
\hline $60 \leq \mathrm{p}<76$ & Cukup \\
\hline $55 \leq \mathrm{p}<60$ & Kurang \\
\hline $\mathrm{p}<55$ & Sangat Kurang \\
\hline Hasil pengolahan & data selanjutnya
\end{tabular}

diinterpretasikan. Interpretasi tersebut digunakan untuk memperoleh gambaran self regulation mahasiswa Pendidikan Matematika FKIP UNRI di masa pandemi Covid-19.

\section{HASIL DAN PEMBAHASAN}

Data skor self regulation mahasiswa yang diperoleh pada penelitian ini diolah untuk dapat memperoleh gambaran mengenai self regulation mahasiswa Pendidikan Matematika FKIP Universitas Riau. Skor self regulation masingmasing mahasiswa dikelompokkan ke dalam kategori self regulation yang telah ditentukan sebelumnya pada Tabel 1. Hasil pengelompokan tersebut, dapat dilihat pada Tabel 6 berikut. 
Hesty Marwani Siregar dan Syarifah Nur Siregar

Anargya: Jurnal Pendidikan Matematika, Vol. 4 No.1, April 2021

https://dx.doi.org/10.24176/anargya.v4i1.5601

Tabel 6. Hasil pengelompokan self regulation mahasiswa

\begin{tabular}{ccc}
\hline Kategori & Jumlah & Persentase \\
\hline Sangat rendah & 0 & 0 \\
\hline Rendah & 0 & 0 \\
\hline Sedang & 21 & 17,36 \\
\hline Tinggi & 80 & 66,12 \\
\hline Sangat tinggi & 20 & 16,53
\end{tabular}

Berdasarkan tabel tersebut, terlihat bahwa

self regulation mahasiswa berada pada kategori sedang, tinggi, dan sangat tinggi. Sebanyak 21 orang mahasiswa berada pada kategori sedang, 80 mahasiswa berada pada kategori tinggi, dan 20 mahasiswa termasuk kategori sangat tinggi. Hasil ini digambarkan pula dengan diagram lingkaran seperti pada gambar di bawah ini

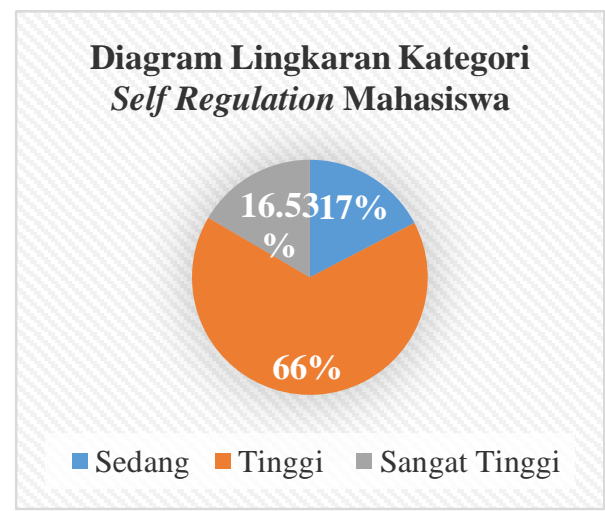

\section{Gambar 1. Diagram Lingkaran Self Regulation Mahasiswa}

Jumlah mahasiswa terbanyak terdapat pada kategori tinggi dengan persentase sebesar $66 \%$, sedangkan kategori sedang dan sangat tinggi memiliki persentase jumlah mahasiswa yang relatif sama yaitu sebesar $17 \%$ dan 16,53\%. Berarti mahasiswa sudah memiliki self regulation yang baik selama mengikuti perkuliahan di masa pandemi Covid-19. Hal ini terlihat dari kondisi mahasiswa selama mengikuti perkuliahan. Selama mengikuti perkuliahan daring, sebagian mahasiswa sudah memiliki target yang akan dicapai dari setiap mata kuliah yang diikuti. Selain itu, mahasiswa juga sudah berusaha mengkondisikan suasana dan keadaan sekitar selama mengikuti perkuliahan daring, misal dengan cara memilih tempat yang tenang dan dapat menjangkau sinyal internet serta tidak mengerjakan pekerjaan lain selama mengikuti perkuliahan daring. Selanjutnya, dalam mengikuti perkuliahan daring, mahasiswa juga melakukan evaluasi terhadap apa yang telah dan belum mereka pahami.
Pencapaian self regulation mahasiswa yang baik ditunjang dengan adanya perkuliahan secara daring yang berjalan baik. Seperti yang dinyatakan oleh Bates (Suhartono \& Indramawan, 2020), proses belajar yang dilakukan dengan cara daring (dalam jaringan) membawa dampak positif bagi mahasiswa yakni, 1) menambah intensitas interaksi antara mahasiswa dengan dosen, 2) belajar dapat dilakukan dimana saja dan kapan saja, 3) proses belajar mampu menjangkau mahasiswa dalam ruang lingkup yang besar, 4) memudahkan dalam menyempurnakan, menyimpan, dan mengakses materi pembelajaran, 5) dapat menarik minat dan keaktivan mahasiswa, 6) dapat meningkatkan hasil belajar. Sejalan dengan Bates, (Thomson, 2010) berpendapat bahwa belajar daring dapat diakses oleh semua mahasiswa, yang memungkinkan mereka untuk belajar secara mandiri, mendalam, dan sesuai kecepatan mereka masing-masing.

Selanjutnya penulis menentukan persentase pencapaian self regulation untuk masing - masing indikator dan membandingkannya dengan kategori yang telah ditentukan sebelumnya. Perhitungan persentase pencapaian self regulation di masing-masing indikator dilakukan untuk melihat apakah masih ada indikator self regulation yang perlu ditingkatkan. Hasil penentuan persentase pencapaian self regulation mahasiswa dapat dilihat pada Tabel 7 berikut.

Tabel 7. Hasil perhitungan persentase pencapaian self regulation mahasiswa untuk masing-masing indikator

\begin{tabular}{lcc}
\hline \multicolumn{1}{c}{ Indikator } & $\begin{array}{c}\text { Persentase } \\
\text { Pencapaian Self } \\
\text { Regulation }(\%)\end{array}$ & Kategori \\
\hline Penetapan tujuan & 85,74 & Baik \\
\hline $\begin{array}{l}\text { Penataan } \\
\text { lingkungan }\end{array}$ & 80,48 & Baik \\
\hline Strategi tugas & 73,17 & Cukup \\
\hline Manajemen waktu & 63,22 & Cukup \\
\hline Pencarian bantuan & 73,76 & Cukup \\
\hline Evaluasi diri & 87,6 & $\begin{array}{c}\text { Sangat } \\
\text { Baik }\end{array}$ \\
\hline
\end{tabular}

Berdasarkan Tabel 7 tersebut terlihat bahwa pencapaian indikator penetapan tujuan dan penataan lingkungan berada pada kategori baik. Untuk indikator strategi tugas, manajemen waktu, dan pencarian bantuan berada pada kategori cukup. Sedangkan indikator evaluasi diri dengan persentase sebesar 87,6\% termasuk kategori sangat baik. Untuk pencapaian self regulation mahasiswa secara keseluruhan berada 
Hesty Marwani Siregar dan Syarifah Nur Siregar

Anargya: Jurnal Pendidikan Matematika, Vol. 4 No.1, April 2021

https://dx.doi.org/10.24176/anargya.v4i1.5601

pada kategori baik dengan persentase pencapaian sebesar 76,46\%. Perbandingan persentase pencapaian self regulation untuk masing-masing indikator dapat dilihat pada gambar berikut.

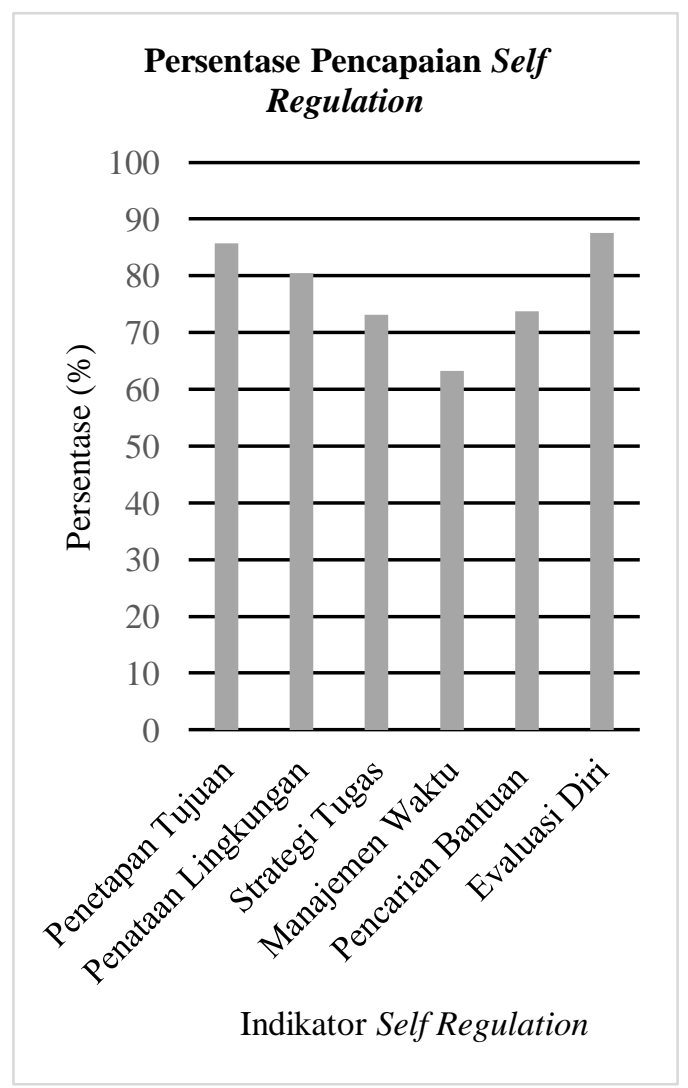

Gambar 2. Persentase pencapaian self regulation untuk masing-masing indikator

Dari gambar, terlihat bahwa persentase pencapaian self regulation tertinggi merupakan indikator evaluasi diri. Persentase pencapaian self regulation tertinggi berikutnya merupakan indikator penetapan tujuan, diikuti indikator penataan lingkungan, pencarian bantuan, strategi tugas, dan manajemen waktu.

Persentase pencapaian self regulation indikator penetapan tujuan berada pada kategori baik, artinya mahasiswa mampu merancang tujuan yang ingin mereka capai dalam belajar. Dalam perkuliahan selama pandemi Covid-19 ini, mahasiswa sudah memiliki arah, tujuan, dan target yang harus mereka capai selama mengikuti perkuliahan. Dengan menetapkan tujuan, mahasiswa dapat mengetahui langkah apa yang harus ditempuh untuk mencapai keberhasilan. Hal ini sesuai dengan pendapat Dotson (2016) yang menyatakan bahwa penetapan tujuan menyebabkan mahasiswa tetap fokus pada hasil yang diinginkan dan memberikan arah yang jelas untuk mencapai keberhasilan.

Indikator lain yang berada pada kategori baik, yaitu penataan lingkungan, artinya mahasiswa sudah memiliki self regulation yang cukup untuk mengatur kondisi lingkungan belajar senyaman mungkin selama pandemi Covid-19. Sehingga meskipun perkuliahan dilakukan secara daring sepenuhnya, mahasiswa tetap dapat berkonsentrasi untuk mengikuti kegiatan belajar. Mahasiswa yang fokus dalam mengikuti kegiatan perkuliahan tentu akan memperoleh hasil yang lebih baik daripada mahasiswa yang kurang fokus mengikuti kegiatan perkuliahan. Kondisi ini sesuai dengan pendapat Ningsih, Haryaka, \& Watulingas (2019), yang menyatakan bahwa lingkungan yang kondusif sangat diperlukan untuk memperoleh hasil belajar yang baik. Lingkungan yang nyaman akan memberikan dampak positif terhadap pencapaian hasil belajar mahasiswa.

Strategi tugas merupakan indikator self regulation yang berada pada kategori cukup. Hal ini terjadi karena hanya beberapa orang mahasiswa yang melakukan persiapan sebelum mengikuti perkuliahan, seperti dengan mempelajari materi yang akan dibahas dan membuat catatan mengenai hal-hal yang belum mereka mengerti. Selain itu, dalam mengikuti perkuliahan, masih banyak mahasiswa yang mengerjakan soal latihan hanya jika disuruh. Bahkan untuk soal-soal yang ditugaskan pun, sebagian mahasiswa hanya menyalin jawaban temannya yang lain. Untuk itu, indikator strategi tugas masih perlu dioptimalkan lagi pencapaiannya. Dengan memiliki strategi tugas yang baik artinya mahasiswa sudah dapat memilih tindakan yang perlu dilakukan agar dapat memahami materi perkuliahan selama pandemi Covid-19. Salah satu bentuk pemilikan strategi tugas yang baik yaitu mahasiswa sudah dapat menyelesaikan tugas yang diberikan dosen secara mandiri dan disiplin. Hal ini tentu akan berpengaruh terhadap pencapaian mahasiswa. Seperti yang dinyatakan oleh Nisa \& Leonard (2018), penyelesaian tugas secara baik, mandiri, dan disiplin dapat meningkatkan hasil belajar mahasiswa.

Kategori indikator manajemen waktu yaitu cukup, bermakna mahasiswa sudah dapat mempergunakan waktu yang dimiliki secara optimal untuk belajar selama pandemi Covid-19. Hal ini dikarenakan masih adanya mahasiswa yang tidak mengalokasikan waktu untuk belajar setiap hari. Beberapa hanya belajar di saat 
Hesty Marwani Siregar dan Syarifah Nur Siregar

Anargya: Jurnal Pendidikan Matematika, Vol. 4 No.1, April 2021

https://dx.doi.org/10.24176/anargya.v4i1.5601

perkuliahan berlangsung, ketika ada tugas, ataupun ketika akan diadakan ujian. Padahal, pengaturan waktu yang baik tentu akan berpengaruh terhadap pencapaian hasil belajar. Sesuai dengan yang dinyatakan Risfandi, Busnawir, \& Sahidin (2014) bahwa mahasiswa menunjukkan hasil belajar yang baik karena mahasiswa mampu mengelola waktu dengan sebaik mungkin, antara kebutuhan untuk belajar dengan kebutuhan untuk melaksanakan kegiatan lainnya.

Indikator pencarian bantuan juga merupakan indikator dengan kategori cukup. Hal ini berarti selama perkuliahan di masa pandemi Covid-19, mahasiswa sudah berusaha menambah pemahaman pada materi yang dirasa sulit dengan bertanya kepada dosen dan teman, serta dengan mempelajari materi dan video yang dapat diakses dengan menggunakan internet. Dengan menentukan bantuan apa yang mereka butuhkan untuk mengatasi kesulitan dalam belajar, mahasiswa dapat meningkatkan hasil belajar mereka. Sesuai dengan yang dikemukakan oleh Sari (2014) bahwa mencari bantuan merupakan salah satu strategi yang dapat dilakukan mahasiswa untuk mengatasi kendala yang dialami saat belajar.

Indikator self regulation berikutnya yakni evaluasi diri mahasiswa, berada pada kategori sangat baik artinya mahasiswa sudah mampu menentukan apakah tindakan yang dilakukan sesuai dengan standar pribadi yang sudah ditetapkan (Dinata, Rahzianta, \& Zainuddin, 2016). Standar pribadi tersebut dipengaruhi oleh standar yang berlaku pada umumnya. Evaluasi diri yang sangat baik menjadi tanda bahwa mahasiswa sudah dapat menilai pencapaian kemajuan belajarnya dan mengetahui apakah pemahaman dan tindakannya sudah sesuai dengan materi yang dipelajari.

Berdasarkan persentase pencapaian self regulation mahasiswa, dapat dilihat bahwa secara umum, pencapaian self regulation mahasiswa sudah baik. Terlihat dari indikator penetapan tujuan dan penataan lingkungan yang berada pada kategori baik, indikator strategi tugas, manajemen waktu, dan pencarian bantuan berada pada kategori cukup, serta indikator evaluasi diri dengan kategori sangat baik. Berdasarkan hasil ini, self regulation mahasiswa masih dapat dikembangkan dengan cara mengoptimalkan indikator yang berkategori cukup.

Mahasiswa dapat mengoptimalkan strategi tugas dengan cara melakukan persiapan sebelum kuliah dimulai melalui membaca materi yang akan dipelajari. Selanjutnya mahasiswa mengikuti perkuliahan dengan baik, mencatat hal-hal yang dianggap penting, membandingkan informasi yang disampaikan dosen dengan informasi yang telah dipelajari sebelumnya. Pada saat diberikan tugas, mahasiswa harus berusaha mengerjakan tugas tersebut secara mandiri, disiplin, dan mencari cara jika menemui kendala dalam pengerjaan tugas tersebut.

Mengoptimalkan indikator manajemen waktu dapat dilakukan dengan cara membuat jadwal harian. Mahasiswa sebaiknya mengalokasikan waktu untuk belajar setiap harinya meskipun pada hari itu tidak ada jadwal perkuliahan ataupun tidak ada tugas yang harus dikerjakan.

Indikator pencarian bantuan juga masih dapat dioptimalkan dengan berusaha mencari berbagai sumber untuk mengatasi kesulitan dalam mempelajari suatu materi. Ketika dengan menonton video masih belum bisa memahami materi pelajaran, mahasiswa dapat bertanya pada dosen atau teman mengenai materi tersebut.

Secara keseluruhan, self regulation mahasiswa Pendidikan Matematika FKIP Universitas Riau selama pandemi Covid-19 berada pada kategori sedang, tinggi, dan sangat tinggi. Ini berarti, mahasiswa sudah mampu beradaptasi untuk mengikuti kegiatan pembelajaran secara daring. Perkuliahan secara daring cukup memberikan dampak positif bagi self regulation mahasiswa dalam belajar. Dengan tercapainya self regulation yang baik, diharapkan mahasiswa dapat memperoleh hasil belajar yang optimal meskipun perkuliahan dilakukan secara daring.

\section{SIMPULAN}

Berdasarkan penelitian yang dilakukan, diperoleh hasil bahwa mahasiswa memiliki self regulation yang baik selama mengikuti perkuliahan di masa pandemi Covid-19. Self regulation mahasiswa berada pada kategori sedang sebanyak 21 orang mahasiswa, kategori tinggi sebanyak 80 orang mahasiswa, dan kategori sangat tinggi sebanyak 20 orang mahasiswa. Sementara, dilihat dari pencapaian self regulation mahasiswa untuk masing-masing indikator, juga diperoleh hasil yang baik, terdiri dari kategori cukup untuk indikator strategi tugas, manajemen waktu, dan pencarian bantuan, kategori baik untuk indikator penetapan tujuan dan penataan lingkungan, serta kategori sangat baik untuk indikator evaluasi diri. Berdasarkan 
Hesty Marwani Siregar dan Syarifah Nur Siregar

Anargya: Jurnal Pendidikan Matematika, Vol. 4 No.1, April 2021

https://dx.doi.org/10.24176/anargya.v4i1.5601

kategori self regulation masing-masing mahasiswa dan persentase pencapaian self regulation untuk setiap indikator, dapat dikatakan bahwa mahasiswa Pendidikan Matematika FKIP Universitas Riau sudah mampu beradaptasi selama mengikuti perkuliahan daring di masa pandemi Covid-19 dengan memiliki self regulation yang baik.

\section{DAFTAR PUSTAKA}

Ahyani, L. N., Pramono, R. B., Astuti, R. D., Kawuryan, F. dan Purwaningrum, J. P. 2019. Evaluation of the Pelita Bullying Prevention Program: A Study of Elementary School Teachers in Kudus, Indonesia. The Open Psychology Journal. $12,147-154$

Alfiana, A. D. 2013. Regulasi Diri Mahasiswa Ditinjau Dari Keikutsertaan Dalam Organisasi Kemahasiswaan. Jurnal Ilmiah Psikologi Terapan, 1(2), 245-259.

Altun, S., \& Erden, M. 2013. Self-Regulation Based Learning Strategies and Self-efficacy Perceptions as Predictors of Male and Female Students' Mathematics Achievement. Procedia - Social and Behavioral Sciences, 106, 2354-2364.

Azwar, S. 2012. Penyusunan Skala Psikologi. Yogyakarta: Pustaka Pelajar.

Barnard, L., Lan, W. Y., To, Y. M., Paton, V. O., \& Lai, S. L. 2009. Measuring SelfRegulation in Online and Blended Learning Environments. Internet and Higher Education, 12, 1-6.

Chairani, L., \& Subandi, M. A. 2010. Psikologi Santri Penghafal Al-Qur'an: Peranan Regulasi Diri. Yogyakarta: Pustaka Pelajar.

Dinata, P. A. C., Rahzianta, \& Zainuddin, M. 2016. Self Regulated Learning sebagai Strategi Membangun Kemandirian Peserta Didik dalam Menjawab Tantangan Abad 21. Prosiding Seminar Nasional Pendidikan Sains (SNPS) VI 2016, 139-146.

Dotson, R. 2016. Goal Setting to Increase Student Academic Performance. Journal of School Administration Research and Development, 1(1), 44-46.

Fathani, A. H. 2019. Pembelajaran Matematika bagi Santri Pondok Pesantren Berbasis Kecerdasan Majemuk. ANARGYA: Jurnal Ilmiah Pendidikan Matematika, 2(1), 4855.

Fung, J. J. Y., Yuen, M., \& Yuen, A. H. K. 2014. Self-Regulation in Learning Mathematics Online: Implications for Supporting
Mathematically Gifted Students with or without Learning Difficulties. Gifted and Talented International, 29(1), 113-123.

Grahani, F. O., \& Mardiyanti, R. 2019. Self Regulated Learning (SRL) Pada Mahasiswa Ditinjau Dari Keikutsertaan Dalam Organisasi. Jurnal Psikologi: Media Ilmiah Psikologi, 17(2), 48-53.

Kusuma, J. W., \& Hamidah, H. 2019. Pengaruh Model Pembelajaran ARIAS dan Cooperative Script terhadap Minat dan Hasil Belajar Matematika. ANARGYA: Jurnal Ilmiah Pendidikan Matematika, 2(1), 64-69.

Manuella, B. D., \& Mangunsong, F. M. 2017. Enhancing an Underachieving Middle School Student's Motivation and SelfRegulation in Learning Mathematics with Self-Regulated Learning Program. Proceedings of the 1st International Conference on Intervention and Applied Psychology (ICIAP 2017), 222-233.

Meisura, A., Risnawati, \& Amir MZ, Z. 2019. Pengaruh Penerapan Strategi Metakognitif Terhadap Kemampuan Pemecahan Masalah Matematis Berdasarkan Kemandirian Belajar siswa. ANARGYA: Jurnal Ilmiah Pendidikan Matematika, 2(1), 13-20.

Mutawah, M. A. Al, Thomas, R., \& Khine, M. S. 2017. Investigation into Self-regulation, Engagement in Learning Mathematics and Science and Achievement among Bahrain Secondary School Students. International Electronic Journal of Mathematics Education, 12(3), 633-653.

Ningsih, S., Haryaka, U., \& Watulingas, J. R. 2019. Pengaruh Motivasi, Lingkungan Belajar, dan Sikap Siswa Terhadap Hasil Belajar Matematika Siswa Kelas VII SMP Negeri 22 Samarinda. Primatika: Jurnal Pendidikan Matematika, 8(1), 43-54.

Nisa, K. K., \& Leonard. 2018. Model Pembelajaran Team Assisted Individualization dengan Strategi Pembelajaran Tugas dan Paksa. Seminar Nasional Dan Diskusi Panel Multidisiplin Hasil Penelitian \& Pengabdian Kepada Masyarakat, 2 Agustus 2018, 472-484.

Purwanto. 2012. Metodologi Penelitian Kuantitatif untuk Psikologi dan Pendidikan. Yogyakarta: Pustaka Pelajar.

Ramdass, D., \& Zimmerman, B. J. 2011. Developing Self-Regulation Skills: The Important Role of Homework. Journal of Advanced Academics, 22(2), 194-218. 
Risfandi, Busnawir, \& Sahidin, L. 2014. Pengaruh Manajemen Waktu Terhadap Hasil Belajar Matematika pada Siswa Kelas VIII SMPS Kartika XX-6 Kendari. Jurnal Penelitian Pendidikan Matematika, 2(1), 126-136.

Sari, D. P. 2014. Meningkatkan Kemampuan Berpikir Kritis Matematis dan Self Regulation Mahasiswa Melalui Pemanfaatan Program Cabri Geometry II pada model Pembelajaran Tutorial. Universitas Pendidikan Indonesia.

Schunk, D. H. 2012. Learning theories: An educational perspective. Yogyakarta: Pustaka Pelajar.

Shereen, M. A., Khan, S., Kazmi, A., Bashir, N., \& Siddique, R. 2020. COVID-19 Infection: Origin, Transmission, and Characteristics of Human Coronaviruses. Journal of Advanced Research, 24, 91-98.

Suhartono, \& Indramawan, A. 2020. Analisis Pengaruh Pembelajaran Daring Terhadap Kemampuan Literasi Bahasa Mahasiswa. Innovative, 8(1), 137-154.

Suprihartini. 2019. Peningkatan Aktivitas dan Hasil Belajar Matematika Tema Pengalamanku Dengan Model Pembelajaran Course Review Horay. ANARGYA: Jurnal Ilmiah Pendidikan Matematika, 2(2), 116-123.

Thomson, D. L. 2010. Beyond the Classroom Walls: Teachers' and Students' Perspectives on How Online Learning Can Meet the Needs of Gifted Students. Journal of Advanced Academics, 21(4), 667-712.

Velayutham, S., Aldridge, J. M., \& Fraser, B. 2012. Gender Differences in Student Motivation and Self-Regulation in Science Learning: A Multi-Group Structural Equation Modeling Analysis. International Journal of Science and Mathematics Education, 10, 1347-1368.

Zamnah, L. N. 2019. Analisis Self-Regulated Learning yang Memperoleh Pembelajaran Menggunakan Pendekatan Problem Centered Learning dengan Hands-on Activity. ANARGYA: Jurnal Ilmiah Pendidikan Matematika, 2(1), 56-63. 